\title{
USE OF MUELLER-HINTON BROTH AND AGAR IN THE GERM TUBE TEST
}

\author{
Antonella Souza MATTEI(1), Sydney Hartz ALVES(2), Cecília Bittencourt SEVERO(3), Luciana da Silva GUAZZELLI(3), \\ Flávio de Mattos OLIVEIRA(3) \& Luiz Carlos SEVERO(1)
}

\begin{abstract}
SUMMARY
Candida albicans is often isolated from clinical samples, thus its presumptive differentiation from other species of the same genus can be based on its ability to form the germ tube in human serum. Nevertheless, there are two other species that share this characteristic: C. dubliniensis and C. africana. The aim of this study was to compare four different substrates to perform the germ tube (GT) test. The Candida spp. isolates were identified using a manual system (135 C. albicans, 24 C. tropicalis and one C. dubliniensis). The germ tube test was performed with fresh, previously frozen serum and Mueller-Hinton (MH) broth and agar. GT was observed in 96\% (130/136) of the isolates through the fresh serum technique, 94\% (128/136) through previously frozen serum, 92\% (125/136) in $\mathrm{MH}$ agar, and $90 \%$ (122/136) in MH broth. The sensitivity of each test was higher than 90\%, with 100\% specificity. Both the MH agar and broth were able to identify the true positives, and false positives were not found. However, some C. albicans isolates were not identified. MH agar and broth may be used in laboratory for the rapid presumptive identification of $C$. albicans, as an alternative method for germ tube test.
\end{abstract}

KEYWORDS: Identification; Germ tube; Mueller-Hinton; Candida albicans.

\section{INTRODUCTION}

The rapid identification of Candida species isolates in clinical laboratories is relevant insofar as the high incidence of candidiasis increases proportionally to the growth in the number of patients at risk for Candida albicans infection ${ }^{4}$.

The quick presumptive differentiation between $C$. albicans and non-C.albicans species is often done based on the ability of the isolates to produce positive germ tubes in blood serum ${ }^{8}$. Nevertheless, there are two other species that share this characteristic: $C$. dubliniensis and $C$. africana were able to form the germ tube 9 . In addition, $C$. tropicalis may produce pseudohyphae which, because of constriction, may make its differentiation more difficult ${ }^{2}$.

A simple, fast, safe and practical method, which can facilitate laboratory routine, is needed to differentiate $C$. albicans from other species $^{1}$. In 2007, a new technique using Mueller-Hinton agar to produce the germ tube was described as being allegedly safer than the conventional method, which uses a blood serum pool that might be contaminated with HIV and hepatitis viruses ${ }^{8}$.

The aim of this study was to compare four different substrates to perform the germ tube (GT) test in $C$. albicans and $C$. dubliniensis isolates.

\section{MATERIAL AND METHODS}

A total of 160 Candida spp. clinical isolates, consisting of $135 C$. albicans, 24 C. tropicalis and one $C$. dubliniensis were obtained from candidiasis in different anatomical sites and identified by the ID $32 \mathrm{C}$ system (bioMérieux ${ }^{\circledR}$, Marcy l’Étoile, France).

For the germ tube test (GT), an inoculum consisted of a single colony of a 24- to 72-hour-old culture for the tubes containing $500 \mu \mathrm{L}$ frozen serum, fresh serum or Mueller-Hinton (MH) broth and a standardized $10 \mu \mathrm{L}$ suspension (0.5 Mac Farland scale) for MH agar, immediately covered by a sterile cover slip. Incubation was performed at $37^{\circ} \mathrm{C}$ for two hours, for all techniques.

Germ tube production in serum and $\mathrm{MH}$ broth was visualized in a conventional way, while the $\mathrm{MH}$-agar plates were visualized using an optical microscope with 10 and 40x lenses.

Results of the four test compounds were compared and their respective sensitivity and specificity were calculated.

The study was approved by the Ethics Committee of Santa Casa de Porto Alegre, Rio Grande do Sul, Brazil.

(1) Faculdade de Medicina, Universidade Federal do Rio Grande do Sul (UFRGS), Brazil. E-mails: antonella.mattei@hotmail.com, severo@ santacasa.tche.br

(2) Departamento de Microbiologia e Parasitologia da Universidade Federal de Santa Maria (UFSM), Rio Grande do Sul, Brazil. E-mail: hartzsa@ smail.ufsm.br

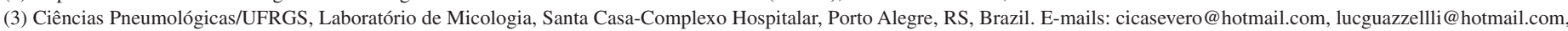
fmodiver@yahoo.com.br

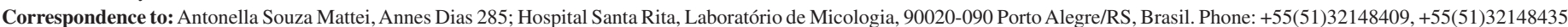

E-mail: antonella.mattei@hotmail.com 


\section{RESULTS}

The germ tube production was observed in $96 \%$ of $C$. albicans and C. dubliniensis isolates (130/136) in fresh serum and $94 \%$ in previously frozen serum (128/136), while $92 \%$ of $\mathrm{MH}$-agar isolates (125/136) and $90 \%$ MH-broth isolates (122/136) produced germ tubes (Table 1). The C. dubliniensis isolate produced true germ tubes in the four substrates.

Table 1

Comparison between the four different substrates, for the production of germ tube in the clinical isolates of Candida spp.

\begin{tabular}{lcccc}
\hline CLINICAL & FROZEN & FRESH & MH & MH \\
ISOLATES & SERUM & SERUM & AGAR & BROTH \\
\hline C. albicans $(\mathrm{n}=135)$ & 129 & 127 & 124 & 121 \\
C. tropicalis $(\mathrm{n}=24)$ & 0 & 0 & 0 & 0 \\
C. dubliniensis $(\mathrm{n}=1)$ & 1 & 1 & 1 & 1 \\
\hline Total & 130 & 128 & 125 & 122 \\
Sensitivity/Specificity & $96 / 100 \%$ & $95 / 100 \%$ & $92 / 100 \%$ & $90 / 100 \%$ \\
\hline
\end{tabular}

MH: Mueller-Hinton.

In the 24 C. tropicalis isolates, the GT was not observed in any of the four substrates, which presented single and multiple budding in blastoconidia and constricted filaments, and could more easily be visualized in agar and $\mathrm{MH}$ broth than in fresh and previously frozen serum.

A larger number of blastoconidia buddings (the average was four cells/field) could be observed in MH broth, as compared to the other three substrates (the average was one cell/field). In addition, GT formation was easily observed in agar and broth, leaving no doubts as to the occurrence or absence of constriction.

The sensitivity and specificity of the GT test on the substrates used ranges from $90 \%$ to $100 \%$, for the rapid presumptive identification of the GT-positive species $C$. albicans and $C$. dubliniensis. Isolates produced only true germ tubes in $\mathrm{MH}$ agar and broth, that is, there was no constriction between the germ tube and the yeast cell; the substrates, however, failed to identify some of the $C$. albicans isolates.

\section{DISCUSSION}

The germ tube test is a rapid and highly reliable test for the presumptive identification of $C$. albicans and it has been widely used for many years. This technique is a simple and cheap alternative to other rapid test methods and may, therefore, be favored by laboratories trying to work economically ${ }^{2,3,4}$. C. albicans GT formation frequently occurs under unfavorable conditions as a consequence of its conversion from yeast into filamentous form, in addition to pseudohyphae occurrence ${ }^{4}$.

The classical method using human serum presents $91 \%$ to $100 \%$ sensitivity and $95 \%$ to $100 \%$ specificity. It has been widely used by laboratories for several years ${ }^{2}$, and the results obtained by this study are in agreement with these parameters.

In spite of its low cost and easiness, the use of human serum for this test has several disadvantages. For example, the serum has to be fresh or frozen; the yeast inoculum has to contain $<10^{7}$ cells $\mathrm{mL}^{-1}$, otherwise, the GT production is inhibited. In addition, the handling of pooled human serum includes the possible risk of infection with HIV or hepatitis virus and different batches of serum may produce different results ${ }^{8}$.

In an attempt to overcome these drawbacks, other media have been proposed, such as animal serum, peptone water, tryptic soy broth (TSB), Sabouraud broth, brain-heart infusion broth (BHI) and RPMI-1640 broth. These media, however, have low sensitivity ${ }^{2}$. KIM et al. ${ }^{4}$, upon comparing GT in rabbit serum at $37^{\circ} \mathrm{C}$ with yeast extract peptone dextrose (YEPD) at $39^{\circ} \mathrm{C}$, observed greater sensitivity and specificity in YEPD.

In this study, GT formation in MH agar, which has already been described by RIMEK et $a l .{ }^{8}$, was easily observed and this points to the possibility of using $\mathrm{MH}$ broth as a favorable medium that could easily differentiate the occurrence or absence of constriction between the extension and the blastoconidium, when compared to the conventional method.

MH agar has been used in Candida spp. susceptibility tests by disc diffusion against fluconazole, amphotericin $\mathrm{B}$, posaconazole, and voriconazole, obtaining results similar to those from the standard medium used, the E-test ${ }^{\circledR 1,5,6}$. Furthermore, the standard medium $\left(\right.$ E-test $\left.^{\circledR}\right)$ is more expensive and requires the use of specific equipment ${ }^{5}$.

Both $\mathrm{MH}$ broth and agar failed to identify some of the $C$. albicans isolates, which could be attributed to the fact that few isolates showed negative GT in these media, on which the switching from yeast form to hyphae is more restricted ${ }^{2}$.

Candida tropicalis can produce germ tube-like structures, which may be confused with true germ tubes after an extended incubation period of three hours. HILMIOGLU et al. ${ }^{2}$ found that an incubation period of two hours resulted in the best specificity. In these experiments, there was no GT formation in C. tropicalis isolates in the four media tested, which indicates $100 \%$ specificity; this had already been confirmed by RIMEK et al. ${ }^{8}$. C. tropicalis is a control strain that produces germ tubelike filaments in the media tested.

\section{CONCLUSION}

MH agar and broth may be used in laboratory for the rapid presumptive identification of $C$. albicans, as an alternative method for the germ tube test.

\section{RESUMO}

\section{Utilização de ágar e caldo Mueller-Hinton na prova do tubo germinativo}

Candida albicans é frequentemente isolada em amostras clínicas, assim a sua diferenciação presuntiva de outras espécies do gênero pode ser baseada na habilidade em formar o tubo germinativo em soro humano. Entretanto, existem outras duas espécies que também possuem essa característica, $C$. dubliniensis e $C$. africana. O objetivo foi comparar quatro diferentes substratos para a realização da prova do tubo germinativo (TG). Utilizou-se isolados de Candida spp. identificados 
através de meio manual (135 C. albicans, 24 C. tropicalis e um $C$. dubliniensis). A prova do tubo germinativo foi realizada utilizando soro previamente congelado e fresco, caldo e ágar Mueller-Hinton ( $\mathrm{MH})$. O TG através da técnica do soro a fresco foi observado em $96 \%$ (130/136), 94\% (128/136) através do soro previamente congelado, 92\% (125/136) no ágar e $90 \%$ (122/136) no caldo $\mathrm{MH}$. A sensibilidade de cada teste foi maior que $90 \%$ e especificidade de $100 \%$. Tanto o caldo quanto o ágar $\mathrm{MH}$ foram capazes de identificar apenas os verdadeiros positivos e não ocorrendo falsos positivos, porém deixaram de identificar alguns isolados de C. albicans. O ágar e o caldo MH podem ser utilizados na rápida e presuntiva identificação laboratorial de C. albicans, como uma alternativa para o teste do tubo germinativo.

\section{ACKNOWLEDGMENT}

The authors would like to thank Coordenação de Aperfeiçoamento de Pessoal de Nível Superior (CAPES).

\section{REFERENCES}

1. Brown S, Traczewski M. Quality control limits for posaconazole disk susceptibility tests on Mueller-Hinton agar with glucose and methylene blue. J Clin Microbiol. 2007;45:222-3.

2. Hilmioglu S, Ilkit M, Badak Z. Comparison of 12 liquid media for germ tube production of Candida albicans and C. tropicalis. Mycoses. 2007;50:282-5.
3. Hoppe J, Frey P. Evaluation of six commercial tests and the germ-tube test for presumptive identification of Candida albicans. Eur J Clin Microbiol Infect Dis. 1999;18:188-91.

4. Kim D, Shin W, Lee K, Kim K, Yong Park J, Koh CM. Rapid differentiation of Candida albicans from other Candida species using its unique germ tube formation at $39^{\circ} \mathrm{C}$ Yeast. 2002;19:957-62.

5. Lee SC, Fung CP, Lee N, See LC, Huang JS, Tsai CJ, et al. Fluconazole disk diffusion test with methylene blue- and glucose-enriched Mueller-Hinton agar for determining susceptibility of Candidas species. J Clin Microbiol. 2001;39:1615-7.

6. Pfaller MA, Barry A, Bille J, Brown S, Ellis D, Meis JF, et al. Quality control limits for voriconazole disk susceptibility tests on Mueller-Hinton agar with glucose and methylene blue. J Clin Microbiol. 2004;42:1716-8

7. Pfaller MA, Boyken L, Messer SA, Tendolkar S, Hollis R, Diekema DJ. Evaluation of the Etest method using Mueller-Hinton agar with glucose and methylene blue for determining amphotericin B MICs for 4,936 clinical isolates of Candida species. J Clin Microbiol. 2004;42:4977-9.

8. Rimek D, Fehse B, Göpel P. Evaluation of Mueller-Hinton-agar as a simple medium for the germ tube production of Candida albicans and Candida dubliniensis. Mycoses. 2008;51:205-8.

9. Romeo O, Criseo G. Morphological, biochemical and molecular characterisation of the first Italian Candida africana isolate. Mycoses. 2008;52:454-7.

Received: 10 December 2013

Accepted: 2 April 2014 